\begin{tabular}{|l|l|l||}
\hline \multicolumn{2}{|c|}{ PublisherInfo } \\
\hline \hline PublisherName & $:$ & BioMed Central \\
\hline \hline PublisherLocation & $:$ & London \\
\hline \hline PublisherImprintName & $:$ & BioMed Central \\
\hline \hline
\end{tabular}

\title{
Macaque advocates seek higher status
}

\begin{tabular}{|l|c|l||}
\hline \multicolumn{2}{|c|}{ ArticleInfo } \\
\hline \hline ArticleID & $:$ & 4582 \\
\hline \hline ArticleDOI & $:$ & $10.1186 /$ gb-spotlight-20020917-01 \\
\hline \hline ArticleCitationID & $:$ & spotlight-20020917-01 \\
\hline \hline ArticleSequenceNumber & $:$ & 248 \\
\hline \hline ArticleCategory & $:$ & Research news \\
\hline ArticleFirstPage & $:$ & 1 \\
\hline \hline ArticleLastPage & $:$ & 3 \\
\hline \hline & & RegistrationDate : 2002-9-17 \\
\hline ArticleHistory & $:$ & OnlineDate \\
\hline \hline ArticleCopyright & $:$ & BioMed Central Ltd2002-9-17 \\
\hline \hline ArticleGrants & $:$ & \\
\hline \hline ArticleContext & $:$ & 130593311 \\
\hline \hline
\end{tabular}




\section{Tabitha M Powledge}

Email: tam@nasw.org

Stung by a second-place finish last May in the race to be officially declared a high-priority genome project, partisans of the rhesus macaque plan to try again. They say they will submit a revamped white paper making the case for Macaca mulatta by the next deadline, 10 October. Judging by recent events, the monkey's chances look good.

One of the three organisms the National Human Genome Research Institute (NHGRI) added to the high-priority bin last week was the formerly obscure but genetically fascinating ciliate Oxytricha trifallax. Along with the rhesus monkey, Oxytricha also had been designated only 'moderate' priority in May. But Oxytricha researchers rewrote the white paper, submitted it by the last deadline, and this time made the cut. "The priority is always subject to re-evaluation and is not a permanent designation," explained Harvard's William M. Gelbart, who heads NHGRI's genome selection committee.

NHGRI made that clear months ago to Jeffrey Rogers of the Southwest Foundation for Biomedical Research in San Antonio, Texas, first author of the rhesus monkey white paper. "I don't want to speak for the genome institute, but they've told me they would like to see a second application," he said.

Rhesus monkey researchers have complained long and loud about finishing behind the chimpanzee in the first high-priority group selected. Funding was, after all, coming from the National Institutes of Health (NIH), and one of NHGRI's main criteria for genome selection was supposed to be medical relevance, they argued.

"I would like to hold NIH's feet to the fire," said Roger Bumgarner, of the Washington Regional Primate Research Center in Seattle, a participant in the monkey genome project. "Nearly all primate research in the US is done in the macaque; very little is done in the chimp for a variety of reasons" he noted. "So the macaque is a better species for medical research." Bumgarner said the new white paper will emphasize how rhesus monkey cDNA and BAC libraries have recently been strengthened, paving the way for researchers to make good use of genome data.

Rogers agrees that biomedical applications have not always been the most significant reason for a particular genome's selection. He cites chicken (selected in May) and cattle (selected last week) as examples. "Clearly the genome institute is willing to make its considerable sequencing capacity available for species where the impact is going to be agricultural or economic, not necessarily primarily biomedical," he said. Bumgarner thinks the process gives too much weight to a genome's attractiveness for basic research. He grumbled, "Sometimes evolutionary interests are taking a higher priority than human health." 


\section{References}

1. National Human Genome Research Institute, [http://www.genome.gov]

2. High-priority genomes announced., [http://genomebiology.com/researchnews/default.asp?arx_id=gbspotlight-20020913-02]

3. US genome sequencing priorities decided., [http://genomebiology.com/researchnews/ default.asp?arx_id=gb-spotlight-20020524-02]

4. Southwest Foundation for Biomedical Research, [http://www.sfbr.org/welcome.html]

5. Washington Regional Primate Research Center, [http://www.rprc.washington.edu/] 